PROFESI (Profesional Islam)

Media Publikasi Penelitian; 2018; Volume 15; No 2.

Website: ejournal.stikespku.ac.id

\title{
Efektifitas Pelatihan Midwifery Update Terhadap Peningkatan Pengetahuan Bidan pada Pelayanan Kebidanan di Surakarta
}

\author{
Munaaya Fitriyya \\ ${ }^{1}$ Prodi DIII Kebidanan STIKES PKU Muhammadiyah Surakarta \\ *Email: fie3ya@gmail.com
}

Kata Kunci
Pelatihan,
Midwifery
Update,
Pengetahuan,
Bidan

\begin{abstract}
Abstrak
Bidan sebagai salah satu tenaga kesehatan strategis yang memiliki tugas dan fungsi memberikan pelayanan kebidanan untuk meningkatkan status kesehatan ibu dan anak, khususnya kesehatan reproduksi perempuan dan tumbuh kembang bayi dan balita. Pengawasan kesehatan ibu sebelum hamil sangat menentukan kualitas anak yang akan dilahirkan. Salah satu pelaksanaan yang dapat dilakukan untuk mengatasi masalah diperlukan sebuah terobosan berupa pelatihan Midwifery Update (MU) yang bertujuan untuk menjaga mutu serta meningkatkan pengetahuan, ketrampilan dan kompetensi bidan sehingga dapat memberikan pelayanan berkualitas.Penelitian ini bertujuan untuk mengetahui tingkat pengetahuan dan ketrampilan bidan di Surakarta dalam memberikan pelayanan kebidanan. Metode yang digunakan adalah dengan cara ceramah, diskusi dan demonstrasi. Responden penelitian adalah 36 bidan di Surakarta yang mengikuti pelatihan MU, Untuk mengukur keberhasilan pelatihan MU ini dilakukan dengan cara pretest dan post test sebelum dan sesudah diberikan materi pelatihan MU. Jenis penelitian ini adalah eksperimental dengan desain penelitian one-group pre-post tes design. Teknik sampling dalam penelitian ini menggunakan Total Sampling. Berdasarkan hasil perhitungan wilcoxon dengan $\alpha=0,05$ hitung lebih besar dari $\alpha$ tabel dengan $\alpha$ tabel 0,009, HO ditolak jika nilai asymp sig $<$ nilai $\alpha, 0.009<$ dari 0.05 Sehingga dapat disimpulkan bahwa sangat efektif pelatihan midwifery Update terhadap peningkatan pengetahuan bidan pada pelayanan kebidanan di Surakarta. .
\end{abstract}

\section{Effectiveness of Midwifery Update Training to Increase Knowledge Midwife on Midwifery Services in Surakarta}

\begin{abstract}
Key Words:
Training,

Midwifery

Update,

Knowledge,

Midwife
\end{abstract}

\begin{abstract}
Midwives as one of the strategic health personnel who have duties and functions provide midwifery services to improve maternal and child health status, especially female reproductive health and growth of infants and toddlers. Supervision of maternal health before pregnancy greatly determines the quality of children to be born. One of the implementation that can be done to overcome the problem required a breakthrough in the form of Midwifery Update (MU) training which aims to maintain the quality and improve the knowledge, skills and competence of the midwife so as to provide quality services. This study aims to determine the level of knowledge and skills of midwives in Surakarta in providing midwifery services. The method used is by lecture, discussion and demonstration. The respondents were 36 midwives in Surakarta who attended MU training. To measure the success of $M U$ training is done by pretest and post test before and after given $M U$ training materials. This type of research is experimental with one-group research design prepost test design. Sampling technique in this study using Total Sampling. Based on calculation of wilcoxon with $\alpha=0,05$ count bigger than $\alpha$ table with $\alpha$ table 0,009, $H O$ rejected if asymp value sig <value $\alpha, 0.009<$ from 0.05 So it can be concluded that highly effective midwifery Update training to increase knowledge of midwife on service midwifery in Surakarta
\end{abstract}


PROFESI (Profesional Islam)

Media Publikasi Penelitian; 2018; Volume 15; No 2.

Website: ejournal.stikespku.ac.id

\section{PENDAHUluaN}

Masalah kesehatan di Indonesia masih merupakan masalah yang memerlukan perhatian khusus dari berbagai pihak. Terdapat beberapa indikator yang dapat digunakan dalam menilai derajat kesehatan masyarakat. Salah satunya yaitu dapat digambarkan melalui angka kematian ibu (AKI) dan angka kematian bayi (AKB). Nilai AKI dan AKB menentukan status kesehatan, dan keberhasilan pelayanan program kesehatan ibu dan anak (KIA) diwilayah tersebut (Dinkes Jateng, 2015)

Peranan bidan dalam masyarakat sebagai tenaga terlatih pada Sistem Kesehatan Nasional adalah memberi pelayanan sebagai tenaga terlatih, meningkatkan pengetahuan kesehatan masyarakat, meningkatkan penerimaan gerakan keluarga berencana, memberi pendidikan "dukun beranak", dan meningkatkan sistem rujukan.

AKI menurut World Healthy Organization (WHO) adalah kematian selama kehamilan atau dalam periode 42 hari setelah berakhirnya kehamilan, akibat semua sebab yang terkait dengan atau diperberat oleh kehamilan atau penanganannya, tetapi bukan disebabkan oleh kecelakaan atau cidera. AKB adalah jumlah kematian bayi dibawah usia 1 tahun per 1000 kelahiran hidup. Angka ini merupakan indikator yang sensitif terhadap ketersediaan, pemanfaatan dan kualitas pelayanan kesehatan terutama pelayanan perinatal (Profil kesehatan Indonesia 2014, 2015).

Menurut Departemen Kesehatan kematian ibu juga disebabkan oleh perdarahan, tekanan darah yang tinggi saat hamil (eklampsia), infeksi, persalinan macet dan komplikasi keguguran. Sedangkan penyebab langsung kematian bayi adalah Bayi Berat Lahir Rendah (BBLR) dan kekurangan oksigen (asfiksia). Penyebab tidak langsung kematian ibu dan bayi baru lahir adalah karena kondisi masyarakat seperti pendidikan, sosial ekonomi dan budaya. Kondisi geografi serta keadaan sarana pelayanan yang kurang siap ikut memperberat permasalahan ini. Beberapa hal tersebut mengakibatkan kondisi 3 terlambat (terlambat mengambil keputusan, terlambat sampai di tempat pelayanan dan terlambat mendapatkan pertolongan yang adekuat) dan 4 terlalu (terlalu tua, terlalu muda, terlalu banyak, terlalu rapat jarak kelahiran) (Depkes, 2010).
Kementrian kesehatan menargetkan penurunan AKI di Indonesia pada tahun 2015 adalah 102 kematian per 100.000 kelahiran hidup dan penurunan angka kematian bayi (AKB) pada tahun 2015 adalah menjadi 22 kematian per 1.000 kelahiran hidup. Namun berdasarkan hasil survey Penduduk Antar Sensus (SUPAS) 2015 AKI di Indonesia yaitu 305 kematian ibu per 100.000 kelahiran hidup, sedangkan AKB sebesar 22,23 per 1.000 kelahiran hidup (Profile Kesehatan Indonesia, 2015).

Pada tahun 2015 AKI di Provinsi Jawa Tengah mencapai 111,16 per 100.000 kelahiran hidup, ini terjadi penurunan yang signifikan dibandingkan tahun 2014 yaitu AKI mencapai 126,55 per 100.000 kelahiran hidup. Sedangkan jumlah AKB pada tahun 2015 mencapai 10 per 1.000 kelahiran hidup, terjadi penurunan tetapi tidak signifikan dibandingkan jumlah AKB pada tahun 2014 yaitu 10,8 per 1.000 kelahiran hidup (Dinkes Jateng, 2015).

Jumlah AKI di kota Surakarta pada tahun 2014 mencapai $71.35 \%$, jumlah tersebut mengalami peningkatan dari tahun 2013 yang hanya mencapai 30,20\%. Hasil cakupan tahun 2014 ini belum mencapai target yang ditetapkan dalam rencana strategis Dinas Kesehatan Kota Surakarta Tahun 2011-2015 yaitu 71\%. Berdasarkan jumlah AKI di Kota Surakarta pada tahun 2014, penyebab kematian ibu didominasi oleh perdarahan, hipertensi, PEB, infeksi (KPD) sedangkan jumlah AKB di Kota Surakarta pada tahun 2014 berdasarkan laporan dari Puskesmas ditemukan bayi mati sejumlah 47 bayi, sedangkan jumlah kelahiran bayi hidup sebanyak 9.811. Dari data tersebut didapatkan angka kematian bayi sebesar 4.79 per 1.000 kelahiran hidup. Dari jumlah AKB, 47 kematian bayi terjadi karena asfiksia, BBLR, premature, kelainan konginetal, jantung bawaan, pneumonia, hipoksia, kelainan paru dan ikterik (Profil Kesehatan Kota Surakarta Tahun 2014).

Peran bidan memberi asuhan kebidanan melalui konsultasi serta rujukan pada masa persalinandengan penyulit tertentu dengan melibatkan klien dan keluarga, mencakup :

a. Mengkaji adanya penyulit dan kondisi kegawatdaruratan pada ibu dan persalinan yang memerlukan konsultasi dan rujukan.

b. Menentukan diagnosis, prognosis, dan prioritas. 
c. Memberi pertolongan pertama pada kasus yang memerlukan rujukan.

d. Merujuk klien untuk keperluan intervensi lebih lanjut pada petugas/ institusi pelayanan kesehatan yang berwenang.

e. Membuat pencatatan dan pelaporan serta serta mendokumentasikan sell kejadian dan intervensi (Maramis, WF 2006)

Upaya untuk menurunkan angka kematian ibu, bayi, dan anak salah satunya dengan asuhan kebidanan berkesinambungan. Asuhan kebidanan berkesinambungan merupakan suatu asuhan yang berkualitas yang diberikan secara continuity of care oleh seorang bidan terhadap klien/ pasien mulai dari masa prakonsepsi, masa kehamilan, persalinan, nifas, dan KB berdasarkan standar asuhan kebidanan yang diberikan yang dapat dilakukan secara mandiri, kolaborasi atau rujukan dalam upaya menjaga kesehatan ibu secara fisik dan psikologi serta deteksi dini komplikasi dan penyulit yang memerlukan tindakan segera. Kejadian AKI dan AKB juga dapat ditekan dengan memberikan asuhan berkesinambungan karena komplikasi selama kehamilan sampai masa nifas dapat terdeteksi sedini mungkin (Profile Kesehatan Indonesia, 2015).

Bidan sebagai salah satu tenaga kesehatan strategis yang memiliki tugas dan fungsi memberikan pelayanan kebidanan untuk meningkatkan status kesehatan ibu dan anak, khususnya kesehatan reproduksi perempuan dan tumbuh kembang bayi \& balita. Banyak ahli telah membuktikan bahwa meningkatkan status kesehatan ibu dan anak dalam mempersiapkan generasi yang berkualitas dimulai sejak dini, yaitu sejak sebelum hamil atau bahkan dimulai dari masa remaja sesuai dengan siklus kesehatan reproduksi perempuan. Pengawasan kesehatan ibu sebelum hamil sangat menentukan kualitas anak yang akan dilahirkan. Demikian juga pengawasan kehamilan dan persiapan kelahiran serta kesiapan menjadi orang tua merupakan bagian yang sangat penting menjadi perhatian seorang bidan. Disamping itu bidan sebagai mitra perempuan dan menjadi role model bagi keluarga, oleh karena itu kesiapan bidan untuk memberikan pelayanan kebidanan berkualitas, menjadi kebutuhan yang mendasar. Selain itu dalam memberikan pelayanan kesehatan masyarakat tersebut bidan harus mematuhi peraturan perundangan yang berlaku ( PP IBI, 2015) .
Salah satu pelaksanaan yang dapat dilakukan untuk mengatasi masalah diperlukan sebuah terobosan berupa pelatihan Midwifery Update (MU) yang bertujuan untuk menjaga mutu serta meningkatkan pengetahuan, ketrampilan dan kompetensi bidan sehingga dapat memberikan pelayanan berkualitas terhadap kesehatan ibu, bayi, balita dan kesehatan reproduksi termasuk pelayanan Keluarga Berencana. Pelatihan ini dikemas dengan menggunakan metode yang lebih interaktif. Seteleh diberikan pelatihan diharapkan pengetahuan dan ketrampilan bidan di Surakarta dalam memberikan pelayanan kebidanan meningkat.

\section{METODE PENELITIAN}

Jenis penelitian ini adalah eksperimental dengan desain penelitian one-group pre-post tes design. Pada Penelitian ini populasi seluruh bidan diSurakarta yang mengikuti pelatihan Midwifery Update angkatan ke 17 yaitu sejumlah 36 orang. Teknik sampling dalam penelitian ini menggunakan Total Sampling. Variabel penelitian ini adalah efektifitas pelatihan Midwefery Update terhadap peningkatan pengetahuan bidan sebagai variabel bebas dan pelayanan kebidanan di Surakarta sebagai variabel terikat. Tehnik pengumpulan data dalam penelitian ini menggunakan metode tes dan praktek. Uji validitas dalam penelitian ini menggunakan non para-metric test .Instrument ini dikatakan valid apabila $\alpha=0,05$ hitung lebih besar dari $\alpha$ tabel dengan $\alpha$ tabel 0,009 , HO diolak jika nilai asymp sig $<$ nilai $\alpha$.

\section{HASIL DAN PEMBAHASAN}

\subsection{Karakteristik Responden}

\section{Umur Bidan}

Distribusi frekuensi berdasarkan usia responden sebagai tenaga penyedia pelayanan kebidanan.

Tabel 1. Distribusi Frekuensi Berdasarkan Umur Responden

\begin{tabular}{ccr}
\hline Usia & Jumlah & Prosentase \\
\hline $25-30$ tahun & 21 & $58 \%$ \\
$31-40$ tahun & 11 & $31 \%$ \\
$41-50$ tahun & 2 & $0,5 \%$ \\
$51-60$ tahun & 2 & $0,5 \%$ \\
Jumlah & 36 & $100 \%$ \\
\hline
\end{tabular}


PROFESI (Profesional Islam) Media Publikasi Penelitian; 2018; Volume 15; No 2.

Website: ejournal.stikespku.ac.id

Berdasarkan tabel 1 menunjukkan bahwa umur responden penelitian cukup merata untuk semua kelas interval. Interval usia paling banyak usia 25 - 30 tahun sebanyak 21 responden (58\%) dan paling sedikit interval usia $41-50$ tahun dan usia 51-60 tahun sebanyak 2 responden $(0,5 \%)$.

\section{Jenjang Pendidikan Bidan}

Distribusi frekuensi berdasarkan pendidikan responden sebagai tenaga penyedia pelayanan kebidanan.

Tabel 2. Distribusi Frekuensi Berdasarkan Pendidikan Responden

\begin{tabular}{ccr}
\hline Pendidikan & Jumlah & Prosentase \\
\hline DIII & 28 & $78 \%$ \\
DIV & 3 & $10 \%$ \\
S 2 & 5 & $12 \%$ \\
Jumlah & 36 & $100 \%$ \\
\hline
\end{tabular}

Berdasarkan tabel 3 menunjukkan bahwa pendidikan responden terbanyak adalah lulusan DIII sebanyak 28 responden (78\%) dan S2 sebanyak 5 responden (12\%).

\subsection{Analisis Univariat}

\section{Pengetahuan}

Pengetahuan bidan sebelum perlakuan adalah berpengetahuan baik yaitu sebanyak 16 responden (44\%) dan sedangkan yang berpengetahuan kurang baik yaitu sebanyak 20 responden (56\%). Setelah perlakuan berpengetahuan baik yaitu sebanyak 25 responden $(70 \%)$ dan sedangkan yang berpengetahuan kurang baik yaitu sebanyak 11 responden (30\%). Gambaran pengetahuan ibu tentang pelayanan kebidanan ditampilkan dalam tabel sebagai berikut:

Tabel 3. Distribusi Tingkat Pengetahuan Pre Test

\begin{tabular}{ccr}
\hline $\begin{array}{c}\text { Tingkat } \\
\text { Pengetahuan }\end{array}$ & Jumlah & Prosentase \\
\hline Baik & 16 & $44 \%$ \\
Kurang baik & 20 & $56 \%$ \\
Jumlah & 36 & $100 \%$ \\
\hline
\end{tabular}

Tabel 4 Distribusi Tingkat Pengetahuan Pre Test

\begin{tabular}{ccr}
\hline $\begin{array}{c}\text { Tingkat } \\
\text { Pengetahuan }\end{array}$ & Jumlah & Prosentase \\
\hline Baik & 25 & $70 \%$ \\
Kurang baik & 11 & $30 \%$ \\
Jumlah & 36 & $100 \%$ \\
\hline
\end{tabular}

Berdasarkan tabel 3 menunjukkan bahwa bidan berpengetahuan baik tentang pelayanan kebidanan masih rendah yaitu 16 responden (44\%). Dan berdasarkan tabel 4 mengalami kenaikan yaitu $25 \%(70 \%)$. Hasil ini diasumsikan karena mayoritas bidan sudah berpendidikan DIII dan materi yang disampaikan bukan materi baru tetapi mengupdate ilmu kebidanan yang sudah mereka dapatkan. Pendidikan D-III berhubungan dengan kemampuan responden untuk memahami informasi-informasi yang mereka terima tentang standar pelayanan antenatal baik pengertian maupun tujuannya. Hal ini seperti yang diungkapkan Mubarok (2011) faktor-faktor yang mempengaruhi pengetahuan diantaranya pendidikan, pekerjaan, umur, minat, pengalaman, kebudayaan lingkungan sekitar dan informasi. Pengetahuan adalah kesan didalam pikiran manusia sebagai hasil penggunaan pancainderanya. Pengetahuan adalah segala apa yang diketahui berdasarkan pengalaman yang didapatkan oleh setiap manusia. Individu cenderung bertehnik sesuai dengan pengetahuan, kesadaran dan sikap terhadap stimulasi. Serta seperti yang diungkapkan Notoatmodjo dalam buku Wawan dan Dewi (2010) pengetahuan sangat erat kaitannya dengan pendidikan tinggi, maka orang tersebut akan semakin luas pula pengetahuannya. Namun perlu ditekankan bahwa seseorang yang berpendidikan rendah tidak berarti mutlak berpengetahuan rendah pula.

Selanjutnya bisa diasumsikan karena usia yang mayoritas umur responden dalam penelitian yaitu pada usia $25-30$ tahun. Hal ini diasumsikan bahwa usia 25-30 tahun merupakan usia yang mencapai matang dalam berfikir serta sudah mencapai sempurna kedewasaan dan budi pekertinya. Maka semakin cukup umur seseorang, semakin matang dalam berfikir dan bekerja, sehingga mereka bisa menerapkannya dalam pekerjaan. Hal ini sesuai yang diiungkapkan Notoatmodjo dalam buku Wawan dan Dewi 
(2010), semakin cukup umur, tingkat kematangan, dan kekuatan seseorang akan lebih matang dalam berfikir dan bekerja. Dari segi kepercayaan masyarakat seseorang yang lebih dewasa dipercaya daripada orang yang belum tinggi kedewasaannya. Bertambahnya usia seseorang akan terjadi pula perubahan aspek fisik dan mentalnya, pada aspek mental taraf berfikir seseorang akan semakin matang dan dewasa.

\subsection{Analisis Bivariat}

Berdasarkan hasil perhitungan wilcoxon pada tabel 6 dengan $\alpha=0,05$ hitung lebih besar dari $\alpha$ tabel dengan $\alpha$ tabel 0,009 , H0 ditolak jika nilai asymp sig $<$ nilai $\alpha, 0.009<$ dari 0.05 maka $\mathrm{H}_{0}$ ditolak dan $\mathrm{Ha}$ diterima. Sehingga dapat disimpulkan bahwa sangat efektif pelatihan midwifery Update terhadap peningkatan pengetahuan bidan pada pelayanan kebidanan di Surakarta .

Menurut Notoatmodjo dalam buku Wawan dan Dewi (2010) pengetahuan atau kognitif merupakan domain yang sangat penting untuk terbentuknya tindakan seseorang (ovent behavior) karena perilaku baru didasari oleh pengetahuan. Kesadaran dan sikap positif tidak dapat bersifat langgeng (long lasting) dari perilaku yang tidak didasari oleh pengetahuan dan kesadaran.

Menurut teori Lawrience Green (1980) dalam Sriningsih (2010) bahwa pengetahuan seseorang atau masyarakat tentang kesehatan ditentukan oleh pengetahuan, sikap, kepercayaan dan tradisi sebagai faktor predisposisi disamping faktor pendukung seperti lingkungan fisik, prasarana dan faktor pendorong yaitu sikap dan perilaku petugas kesehatan atau petugas lainnya. Tindakan yang diharapkan mungkin tidak akan terjadi kecuali seseorang mendapat isyarat yang kuat untuk memotivasinya bertindak atas dasar pengetahuan yang dimiliki. Sebelum seseorang berperilaku positif maka dia harus memilih pengetahuan dan sikap yang mendukung terlebih dahulu mengenai sesuatu hal tersebut. Sebab jika tidak, perilaku yang akan dihasilkan tidak akan maksimal.

Menurut Notoatmodjo dalam buku Wawan dan Dewi (2010) pengetahuan seseorang tentang suatu objek mengandung dua aspek yaitu aspek positif dan aspek negatif. Kedua aspek ini akan menentukan sikap seseorang, semakin banyak aspek positif dan objek yang diketahui, maka akan menimbulkan sikap makin positif terhadap objek tertentu. Peneliti berasumsi jika bidan mempunyai pengetahuan yang beraspek positif tentang materi pelatihan maka akan menimbulkan sikap yang positif pula, lalu semakin baik pengetahuan bidan dalam pelayanan kebidanan yang meliputi APN, Neonatus dan KB.

Menurut Sulistyawati (2009) Dalam pelaksanaan program kesehatan dibutuhkan sumber daya manusia yang kompeten, sehingga apa yang menjadi tujuan pembangunan tercapai. Bidan sebagai salah satunya yang merupakan ujung tombak dalam memberikan pelayanan kesehatan kepada wanita harus mempunyai pengetahuan yang luas mengenai ilmu kebidanan. Dengan peran yang besar ini maka sangat penting bagi bidan untuk selalu meningkatkan kompetensinya.

\section{SIMPULAN}

a. Interval usia paling banyak usia $25-30$ tahun sebanyak 21 responden (58\%)

b. Pendidikan responden terbanyak adalah lulusan DIII sebanyak 28 responden $(78 \%)$

c. Sangat efektif pelatihan Midwifery Update terhadap peningkatan pengetahuan bidan pada pelayanan kebidanan di Surakarta dengan $\alpha=$ 0,05 hitung lebih besar dari $\alpha$ tabel dengan $\alpha$ tabel 0,009 .

\section{REFERENSI}

Arikunto, S. 2010. Pendidikan dan Perilaku kesehatan. Jakarta: Rineka Cipta

S. 2010. Promosi Kesehatan dan Ilmu Perilaku. Jakarta: Rineka Cipta

Dinas Kesehatan Kotamadya Surakarta Profil Kesehatan Kota Surakarta Tahun 2014. Surakarta

Dinas Kesehatan Profinsi Jawa Tengah 2015. Profile Kesehatan Jawa Tengah 2015. Semarang

Fais, M \& Saleha, S. 2009. Buku Ajar Organisasi Dan Manajemen Pelayanan Kesehatan Serta Kebidanan. Jakarta: Salemba Medika

Ida Ayu Chandranita (2009) Memahami Kesehatan reproduksi wanita ed 2 EGC.Jakarta 
PROFESI (Profesional Islam) Media Publikasi Penelitian; 2018; Volume 15; No 2.

Website: ejournal.stikespku.ac.id

Kemenkes RI ,2015.Profil Kesehatan Indonesia 2014. Jakarta

I.B.Wirawan, 2012. Teori- teori dalam tiga paradigma.Prenada media grup 2012 Jakarta

Maramis, WF. (2006). Ilmu Perilaku Dalam Pelayanan Kesehatan. Surabaya: Airlangga Mardiana.
PP IBI. (2001). Bidan Menyongsong Masa Depan. Jakarta

Soepardan, Hj. Suryani. (2007). Konsep Kebidanan. Jakarta : EGC.

Wawan, A \& Dewi. 2010. Pengetahuan Sikap dan Perilaku Manusia. Yogyakarta: Nuha Medika 